\title{
Metabolism of ingested lipids by North Atlantic right whales
}

\author{
Zachary T. Swaim ${ }^{1,2}$, Andrew J. Westgate ${ }^{1,2}$, Heather N. Koopman ${ }^{1,2, *}$, \\ Rosalind M. Rolland ${ }^{3}$, Scott D. Kraus ${ }^{3}$ \\ ${ }^{1}$ University of North Carolina Wilmington, 601 S. College Rd., Wilmington, North Carolina 28403, USA \\ ${ }^{2}$ Grand Manan Whale and Seabird Research Station, Grand Manan, New Brunswick E5G 1A1, Canada \\ ${ }^{3}$ New England Aquarium, Central Wharf, Boston, Massachusetts 02110, USA
}

\begin{abstract}
North Atlantic right whales Eubalaena glacialis feed predominantly on Calanus finmarchicus Stage V copepods. Calanus possesses 2 classes of storage lipids, triacylglycerols (TAG) and wax esters (WE), the latter comprising $94 \%$ of total lipids. Most mammals are incapable of metabolizing WE and thus eliminate it in their feces. The objective of this study was to determine whether right whales are capable of metabolizing both TAG and WE. We compared the lipid composition of copepods collected during plankton tows $(n=64)$ over 2 summers $(2006$ and 2007) with the lipid composition of 24 right whale fecal samples collected synoptically in the Bay of Fundy. Using ingestion and defecation models, we estimated that an average right whale (40000 kg) ingests $\sim 58000 \mathrm{~g}$ of WE d $\mathrm{W}^{-1}$ but eliminates only $250 \mathrm{~g}$ of WE, implying that right whales are assimilating over $99 \%$ (57765 g) of dietary WE. Lipids in the feces differed significantly from those of the diet. Copepod lipids were dominated by saturated fatty acid (FA) components 14:0 (14.73 \pm 0.32 wt\%) and 16:0 $(8.99 \pm 0.20 \mathrm{wt} \%)$, with monounsaturated and polyunsaturated components comprising the remainder. Long chain monounsaturated 20:1n-9 and 22:1n-11 dominated the fatty alcohol composition of copepods. Fecal lipid composition consisted primarily of saturated FA, many of which were absent in the copepods. These data suggest that right whales have evolved an unusual metabolic capability, such as specialized enzymatic machinery or a gut symbiont, which, unlike other mammals, enables them to utilize most of their WE-rich diet.
\end{abstract}

KEY WORDS: Eubalaena glacialis $\cdot$ Right whale $\cdot$ Lipid metabolism · Wax ester · Triacylglycerol · Calanus finmarchicus $\cdot$ Copepod $\cdot$ Feeding

\section{INTRODUCTION}

Western North Atlantic right whales Eubalaena glacialis have been described as feeding specialists (McKey et al. 1981, McNab 2002), since they forage predominantly on Stage V (C5) calanoid copepodites Calanus finmarchicus (Murison \& Gaskin 1989, Baumgartner \& Mate 2003, Baumgartner et al. 2007). Right whales are thought to preferentially feed on older C5 C. finmarchicus (Murison \& Gaskin 1989, Baumgartner \& Mate 2003) because they contain the highest caloric content of any copepod life stage (Comita et al. 1966). In the Bay of Fundy, C5 copepods are most abundant during the mid to late summer months, when right whales are present in the greatest numbers (Murison \& Gaskin 1989, Woodley \& Gaskin 1996, Baumgartner et al. 2003, Michaud \& Taggart 2007). Murison \& Gaskin (1989) and Baumgartner \& Mate (2003) showed that C5 C. finmarchicus inhabit depths below $100 \mathrm{~m}$ and are the dominant zooplankton near feeding right whales. Right whales have been shown to selectively forage on these dense deep-water aggregations (Baumgartner et al. 2007).

Calanoid copepods have 2 types of storage lipids, triacylglycerols (TAG) and wax esters (WE) (Michaud \& Taggart 2007). Although the relative proportions of these 2 major lipid classes vary inter-specifically, seasonally and with food abundance (Sargent et al. 1976, 
Kattner et al. 2007, Michaud \& Taggart 2007), during mid to late summer C5 copepods consist almost entirely of WE (Michaud \& Taggart 2007). Thus, during the summer in the Bay of Fundy, right whales are consuming large quantities of WE.

In most mammals, TAG are rapidly metabolized and are more efficiently hydrolyzed than WE, and thus constitute the primary form of ingested and stored lipids (Savory 1971, Patton \& Benson 1975, Sargent 1976, Place 1992a). In contrast, the limited number of studies available suggest that WE are not well digested by mammals (Hansen \& Mead 1965, Place 1992a). WE are more common in marine systems (Sargent 1976) and may be used more efficiently by marine organisms. While several studies have indicated that some marine fish species (Patton \& Benson 1975, Patton et al. 1975, Sargent et al. 1979, Mankura et al. 1984, Olsen et al. 2004) and pelagic seabirds (Warham 1977, Jacob 1982, Obst 1986, Roby et al. 1986) metabolize WE, there has been little work investigating WE metabolism in mammals.

Nordøy (1995) showed that minke whales Balaenoptera acutorostrata were capable of digesting WE by examining lipid class composition of fresh undigested forestomach and colon contents of dead whales and comparing those measurements with previously determined digestibility estimates of krill using in vitro techniques (Nordøy et al. 1993). The results of Nordøy (1995) suggested that minke whales could digest $92 \%$ of ingested WE. While these studies leave little doubt about the ability of minke whales to digest WE, the predicted assimilation rates were based on results from in vitro experiments (Nordøy et al. 1993) rather than the actual digestive processes of a living whale.

During summer in the Bay of Fundy, it is possible to collect right whale fecal material because it is clumped and floats after defecation (Rolland et al. 2007). Therefore, we were able to use fresh fecal samples to determine whether right whales were capable of assimilating all of the lipid energy they ingest, using the reasoning that indigestible lipids would pass through the alimentary canal and be expelled. The fact that the feces float suggests that some lipid may be present, but the lipid composition of right whale fecal samples had not previously been quantified.

North Atlantic right whales are one of the most endangered species of large whales (Clapham et al. 1999), with approximately 350 individuals remaining in the population (Kraus \& Rolland 2007). Right whale populations have suffered severe declines due to historical over-exploitation from whaling, and, more recently, anthropogenic mortality from ship strikes (Knowlton \& Brown 2007) and fishing-gear entanglement (Johnson et al. 2007). There is also evidence of decreased reproductive rates in this population, partic- ularly during the 1990s (Knowlton \& Kraus 2001, Kraus et al. 2001, 2007). Population models using data through the late 1990s suggested that right whales would become extinct within the next 2 centuries if the trends in mortality and reproduction continued (Caswell et al. 1999, Fujiwara \& Caswell 2001). The importance of understanding the physiology of a species in order to guide its conservation has recently become more apparent (e.g. Wikelski \& Cooke 2006). Our study fits into the 'conservation physiology' framework by considering whether the nutritional quality of right whale diets is accurately reflected both in energetic models and in assumptions of the biomass and densities of copepods that are necessary to support right whales in different portions of their habitat.

The primary objectives of this study were to (1) determine the lipid content and composition of right whale fecal material collected in the Bay of Fundy; (2) determine the lipid content and composition of the primary prey of right whales, C5 Calanus finmarchicus; (3) evaluate whether right whales were capable of metabolizing all of the lipid in their diet by comparing the lipids an average right whale consumes with those that are eliminated in the fecal material (considering lipid content, lipid class composition, and fatty acid and fatty alcohol composition); and (4) estimate daily lipid assimilation of right whales using allometrically derived right whale ingestion and defecation rates in conjunction with data on copepod and fecal lipid composition.

\section{MATERIALS AND METHODS}

Sample collection. Copepods were collected in the Bay of Fundy between mid-July and September using plankton nets (2006: $\mathrm{n}=23 ;$ 2007: $\mathrm{n}=20$ ). Zooplankton tows were conducted on a weekly basis (weatherdependent) at 2 stations (northern and southern) in the Grand Manan Basin, a major summer feeding habitat for right whales (Fig. 1), to account for potential spatial variability in copepod lipid content or species composition. Copepod samples were also collected from additional locations (Fig. 1; 2006: $\mathrm{n}=14 ; 2007: \mathrm{n}=7$ ), located throughout the Bay of Fundy, to evaluate whether spatial variation in copepod lipid content or composition existed on a wider scale.

Plankton tows were carried out aboard a $6 \mathrm{~m}$ fiberglass boat using a $61 \mathrm{~cm}$ bongo frame with two $300 \mu \mathrm{m}$ mesh nets attached (Sea-Gear Corporation). Nets were lowered to the sea floor, then hauled vertically to the surface at approximately $1 \mathrm{~m} \mathrm{~s}^{-1}$ while the boat was stationary. Sampling depths were recorded using a depth sounder (Raytheon) and ranged from 190 to $210 \mathrm{~m}$ (tide-dependent) at both north and south locations. 


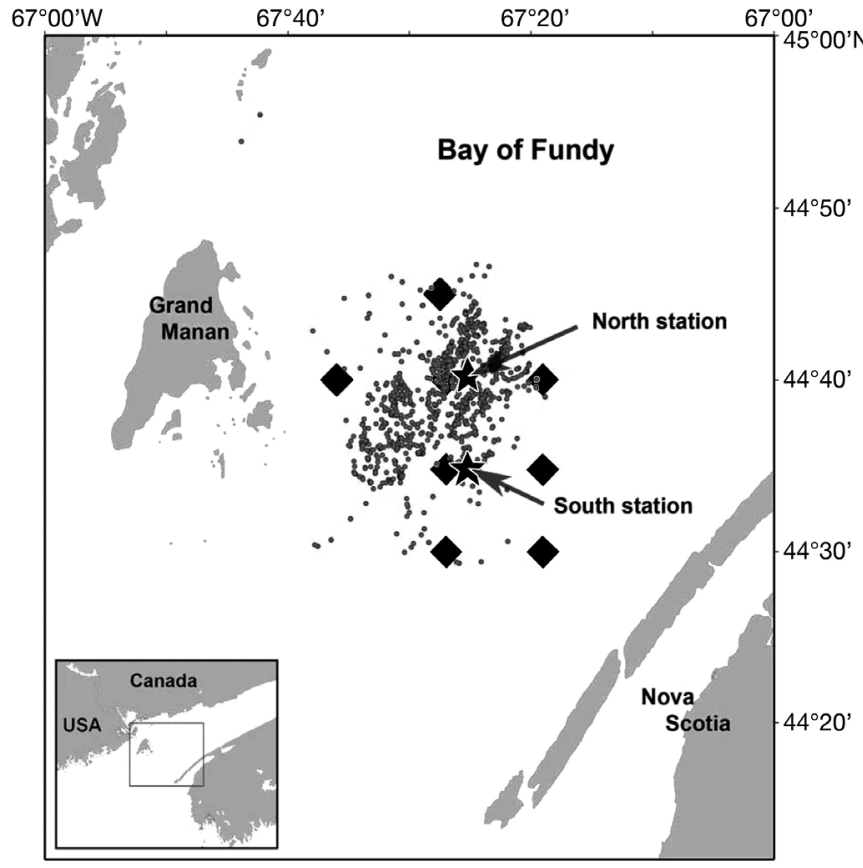

Fig. 1. Calanus finmarchicus and Eubalaena glacialis. Zooplankton sampling locations in the Bay of Fundy. Net sampling was conducted within the Grand Manan Basin at 2 specific locations (northern and southern $\star$ ) within the major right whale summer feeding habitat (based on sightings data collected between 1987 and 2000; Right Whale Consortium 2008). Right whale sightings data collected by the New England Aquarium in 2006 and 2007 (•) further validate that zooplankton tows were conducted in a habitat where right whales are commonly seen. Copepod samples were also collected from additional locations $(\diamond)$, to evaluate whether spatial variation in copepod lipid content or composition existed on a wider scale

Zooplankton used for species identification and quantification were collected from one of the nets and transferred to $4 \%$ buffered formalin solution for preservation. The contents of the second net, used for lipid analysis, were stored without preservatives in $15 \mathrm{ml}$ cryovials (Nalgene, Nunc) and frozen in liquid nitrogen. These samples were later transferred to a $-80^{\circ} \mathrm{C}$ freezer until lipid analysis was conducted. Due to problems with the bongo nets, zooplankton were sometimes collected for lipid analysis only; thus sample sizes for lipids and zooplankton quantification are not equal.

Right whale fecal material was collected in 2006 and 2007 during ship-based right whale surveys by the New England Aquarium (NEAq). A $300 \mu$ nylon mesh dipnet (Sea-Gear Corporation) was used to scoop floating fecal material from the water as described by Rolland et al. (2005). Fecal samples used for this study were collected by the NEAq between 9 August and 17 September $2006(\mathrm{n}=16)$ and from 6 through 21 August 2007 ( $\mathrm{n}=6$ ). Additional fecal samples (one each in 2006 and 2007) were collected opportunistically by the Grand Manan Whale and Seabird Research Station. All samples were immediately placed in a cooler on board the vessel and then stored frozen at approximately $-20^{\circ} \mathrm{C}$ until lipid analysis could be conducted.

Zooplankton identification and quantification. Zooplankton samples were well mixed and using a Folsom plankton splitter and taxonomic keys (Gosner 1971, Smith 1977, Roff 1978, Murphy \& Cohen 1979), random sub-samples (approximately 6\%) were examined and counted using a dissecting microscope to determine species composition, quantity and developmental stages. Data were tested for normality; once normal distributions were confirmed (via the Shapiro-Wilks test), ANOVA and $t$-tests $(\mathrm{p}<0.05$ was considered significant) were used to compare differences in zooplankton proportions across sampling months and years.

Lipid extraction and lipid class determination. Macrozooplankton (e.g. euphausiids, pandalids) were removed prior to lipid analysis in order to reduce potential biases introduced by large non-copepod components. The remainder of the zooplankton (heavily dominated by C5 Calanus finmarchicus, see 'Results') was analyzed for lipid content and composition. Lipids were extracted from fecal and copepod samples using a modified Folch et al. (1957) chloroform: methanol procedure as described in Koopman et al. (1996). Lipid was then resuspended in hexane and stored under nitrogen gas at $-20^{\circ} \mathrm{C}$ until further processing. All lipid content data are presented as wet weight values, as this is what the whales would actually be consuming and eliminating. Lipid classes were separated and quantified (Ackman et al. 1990) using thin-layer chromatography with flame ionization detection (TLC-FID) (Iatroscan ${ }^{\circledR}$ Mark VI Mitsubishi Kagaku Iatron), using the following solvent system: 15 min in hexane:diethyl ether (66:4); $15 \mathrm{~min}$ in hexane:ethyl acetate:formic acid (55:15:0.5); 30 min in hexane:benzene solvent (30:30). Rods were scanned at a rate of $30 \mathrm{~s} \mathrm{rod}^{-1}$ using $170 \mathrm{ml} \mathrm{min}{ }^{-1}$ hydrogen and $2000 \mathrm{ml} \mathrm{min}{ }^{-1}$ air flow. Results were integrated with PeakSimple 329 Iatroscan software (SRI Instruments). Identification of peaks was confirmed using known standards (NuCheck Prep, Elysian) of WE, TAG, free alcohols, phospholipids (PL), cholesterol (Chol) and diacylglycerols (described by Koopman et al. 1996). Gas chromatography-mass spectrometry (GCMS) analysis (see next subsection) revealed the presence of sterols. WE and sterol esters (StE) coelute on most solvent systems (Parrish \& Ackman 1983, Hamilton 1995), therefore, WE and StE proportions had to be estimated in the WE/StE peak. A WE:StE ratio was calculated from mean fatty alcohol (FAlc) (major component of $\mathrm{WE}$ ) and mean sterol content (component of StE) 
obtained from gas chromatography (GC) data (see next subsection) and applied to the ester peak recorded by the Iatroscan. As above, $t$-tests and ANOVA were used to compare differences in lipid content and composition in copepod and fecal samples across sampling location, month and year once normality had been confirmed.

Fatty acid and fatty alcohol analyses. Fatty acids (FA) and FAlc components of copepods and feces were converted to butyl esters for GC analysis to capture any short-chain components that might be present (see Koopman et al. 1996). Copepod and fecal FA and FAlc were identified using a Varian capillary 3800 GC with FID (Varian) using a fused silica column $(30 \times 0.25 \mathrm{~mm}$ ID) coated with polyimide ( $0.25 \mu \mathrm{m}$ thickness; Zebron FFAP column; Phenomenex) and helium as the carrier gas $\left(1.0 \mathrm{ml} \mathrm{min}^{-1}\right)$. The following temperature program was used: $65^{\circ} \mathrm{C}$ for $2 \mathrm{~min}$, hold at $165^{\circ} \mathrm{C}$ for $0.40 \mathrm{~min}$ after ramping at $20^{\circ} \mathrm{C} \mathrm{min}{ }^{-1}$, hold at $215^{\circ} \mathrm{C}$ for $6.6 \mathrm{~min}$ after ramping at $2^{\circ} \mathrm{C} \min ^{-1}$, and hold at $250^{\circ} \mathrm{C}$ for 10 min after ramping at $5^{\circ} \mathrm{C} \mathrm{min}{ }^{-1}$. Up to 50 different FA and FAlc were identified according to Iverson et al. $(1997,2002)$ and Koopman et al. (2006). FA and FAlc were described using the nomenclature of $A: B n-X$, where $A$ is the number of carbon atoms, $B$ is the number of double bonds, and $X$ is the carbon position of the double bond closest to the terminal methyl group. These results were integrated with Galaxie Chromatography Data System (Version 1.8.501.1, Varian) software. Copepod and fecal FA and FAlc components were identified on the same run and then confirmed using prepared standards (NuCheck Prep), GCMS (Trace GC Ultra coupled to a Polar Q mass spectrometer) and TLC (Thermo Electron Corporation with X calibur software, using the same FFAP column as above).

To determine whether the overall signatures of the copepods and whale feces were different, FA and FAlc data were compared using a multivariate approach. Fifteen FA (16:0, 16:1n-7, 18:0, 18:1n-9, 18:3n-3, 20:0, 20:1n-9, 20:5n-3, 22:1n-11，22:0，22:6n-3) and FAlc $(16: 0,18: 1 \mathrm{n}-9,20: 1 \mathrm{n}-9,22: 1 \mathrm{n}-11)$ were selected, based on either being dominant components or of physiological importance. FA and FAlc data were arcsine transformed (Steel \& Torrie 1980) and screened for outliers. The 15 FA and FAlc were submitted to a discriminant function analysis (DFA); prior probabilities were unequal (based on sample size). All fecal and copepod cases were then reclassified using discriminant function (DF) scores; leave-one-out classification was also used to determine the robustness of the classification.

Modeling right whale lipid assimilation. To estimate lipid assimilation efficiencies for right whales, total daily ingestion $\left(I_{\mathrm{d}}\right.$, number of copepods $\left.\mathrm{d}^{-1}\right)$ was first calculated using a modified ingestion model (Baumgartner \& Mate 2003):

$$
I_{\mathrm{d}}=A_{\mathrm{g}} S T_{\mathrm{d}} C
$$

where the mouth gape $\left(A_{\mathrm{g}}, 1.21 \mathrm{~m}^{2}\right)$ was based on a $40000 \mathrm{~kg}$ whale (Mayo et al. 2001) and $S\left(1.5 \mathrm{~m} \mathrm{~s}^{-1}\right)$ was the swimming speed (see Baumgartner \& Mate 2003). Duration at depth ( $\left.T_{\mathrm{d}}, 43200 \mathrm{~s}\right)$ was based on the assumption that a right whale will spend between 3 to $12 \mathrm{~h} \mathrm{~d}^{-1}$ foraging to meet its daily metabolic requirements (as described by Kenney et al. 1986); therefore, a $12 \mathrm{~h} \mathrm{~d}^{-1}$ was used as a maximum foraging time. The copepod concentration $(C)$ value was based on mean C5 Calanus finmarchicus density $\left(7481 \mathrm{~m}^{-3}\right)$ in the Bay of Fundy as calculated by Baumgartner \& Mate (2003). The product of these variables resulted in the daily copepod $I_{\mathrm{d}}$. We did not use the copepod density estimates from our own plankton tows because this type of sampling seriously underestimates the actual copepod concentrations that are available to the whales. Zooplankton densities estimated by Baumgartner \& Mate (2003) were calculated using an optical plankton counter (OPC) and currently provide the most accurate estimates of $\mathrm{C} 5$ densities in the Bay of Fundy. In contrast to net sampling, an OPC reports a fine scale estimate of $\mathrm{C} 5$ densities and is not dependent on water column-integrated concentrations which may underestimate $\mathrm{C} 5$ densities. See Baumgartner (2003) for a discussion of C5 C. finmarchicus abundance estimates from nets and OPCs.

To convert $I_{\mathrm{d}}$ to total grams ingested $\mathrm{d}^{-1}\left(I_{\mathrm{g}}, \mathrm{g} \mathrm{d}^{-1}\right)$, individual C5 Calanus finmarchicus $(\mathrm{n}=20)$ were weighed and a mean wet weight of $1.47 \mathrm{mg}$ ind..$^{-1}$ was calculated and multiplied by $I_{\mathrm{d}}$.

$$
I_{\mathrm{g}}=I_{\mathrm{d}}\left(1.47 \mathrm{mg} \mathrm{C} 5 \mathrm{ind}^{-1}\right)
$$

Total lipid ingested $\mathrm{d}^{-1}\left(I_{\mathrm{L}}, \mathrm{g} \mathrm{d}^{-1}\right)$ was determined by multiplying $I_{\mathrm{g}}$ by the mean C5 Calanus finmarchicus percent lipid content value of $7.17 \mathrm{wt} \%$ (mean lipid content value measured from the current study).

$$
I_{\mathrm{L}}=I_{\mathrm{g}}(7.17 \mathrm{wt} \%)
$$

Copepod lipid class data (mean percent of total lipid) were then multiplied by $I_{\mathrm{L}}$ to estimate the amount $(\mathrm{g})$ of each lipid class ingested $\mathrm{d}^{-1}$.

There are very few published data on defecation rates of wild mammals, therefore, it is difficult to estimate the daily fecal production in right whales. Allometric modeling is a useful tool for predicting various ecological and physiological characteristics from body weight ( $W$, in g) (e.g. White \& Seymour 2005, Duncan et al. 2007). Based on allometric models provided by Blueweiss et al. (1978) and Lavigne (1982), combined with fecal lipid content data, it was possible to model approximately how much lipid an average right whale $(W, 40000 \mathrm{~kg})$ eliminates on a daily basis. Blueweiss et 
al. (1978) provided an equation estimating mammal defecation rates $\left(F, g^{-1} \mathrm{~d}^{-1}\right)$ in relation to body size, where:

$$
F=0.85 W^{-0.37}
$$

Lavigne (1982) modified this equation to report total fecal production (FE) on a whole animal basis $\left(\mathrm{g} \mathrm{d}^{-1}\right)$ where:

$$
\mathrm{FE}=0.85 W^{0.63}
$$

It was assumed that an average right whale weighs $40000 \mathrm{~kg}$ (Kenney et al. 1986); therefore by using Eq. (5) it was possible to estimate daily fecal production ( $\mathrm{g}$ feces $\mathrm{d}^{-1}$ ). To determine the amount of lipid a right whale eliminates as fecal material ( $g$ lipid $\left.\mathrm{d}^{-1}\right)$, mean fecal percent lipid (from 2006 and 2007 combined) was multiplied by the estimated right whale fecal production rate. Fecal lipid class data were multiplied by the mean percent lipid content to determine the amount of each component eliminated.

Right whale ingestion and defecation rates were then compared to estimate the amount of lipid assimi- lated. Ingestion and defecation rates were converted to lipid rates $\left(\mathrm{g} \mathrm{d}^{-1}\right)$ and then compared to estimate the amount of lipid that was assimilated per day. Lipid content and class composition were then multiplied by the lipid ingestion and defecation rates to determine the amount of each component that was assimilated per day. All statistical analyses were carried out using SPSS. All means are presented \pm SE.

\section{RESULTS}

\section{Zooplankton identification and species composition}

The dominant zooplankton species present $(\mathrm{n}=46$ samples analyzed for plankton diversity) in 2006 and 2007 from the northern $(\mathrm{n}=18)$, southern $(\mathrm{n}=23)$ and basin-wide $(\mathrm{n}=5)$ tow sites was Calanus finmarchicus (Table 1). In both years, C5 C. finmarchicus dominated all zooplankton samples (2006: $83.5 \pm 1.7 \%$; 2007 : $71.1 \pm 2.3 \%$ ) (Table 1 ), with a significantly smaller percentage in 2007 ( $p=0.004)$. In 2006, there were no sig-

Table 1. Mean \pm SE zooplankton composition (\% frequency of occurrence) of samples collected at the northern and southern tow stations (see Fig. 1) from July through September of 2006 and 2007. One tow in September 2006 and 4 tows in September of 2007 were conducted outside the grid (see Fig. 1) to evaluate spatial variability in zooplankton composition. Numbers in parentheses represent the number of tows

\begin{tabular}{|c|c|c|c|c|c|c|c|}
\hline \multirow[t]{2}{*}{ Taxa } & \multicolumn{3}{|c|}{ North } & \multicolumn{3}{|c|}{ - South - } & \multirow{2}{*}{$\begin{array}{c}\text { Other } \\
\text { Sept (1) }\end{array}$} \\
\hline & July (1) & Aug (2) & Sept (5) & July (1) & Aug (6) & Sept (5) & \\
\hline \multicolumn{8}{|l|}{2006} \\
\hline Calanus finmarchicus (V) & 92.98 & $85.38 \pm 1.19$ & $83.98 \pm 1.58$ & 90.21 & $80.90 \pm 3.21$ & $80.37 \pm 5.02$ & 91.12 \\
\hline C. finmarchicus (adult) & 0.14 & $6.41 \pm 0.56$ & $6.57 \pm 1.09$ & 4.46 & $5.26 \pm 1.04$ & $4.25 \pm 1.13$ & 1.44 \\
\hline C. finmarchicus (IV) & 0.62 & $1.66 \pm 0.07$ & $1.77 \pm 0.81$ & 1.90 & $4.35 \pm 2.13$ & $3.27 \pm 1.77$ & 0.54 \\
\hline C. finmarchicus (III) & - & 0.15 & $0.11 \pm 0.07$ & - & $2.01 \pm 1.75$ & 0.66 & 0.22 \\
\hline C. hyperboreous & 2.40 & $4.15 \pm 0.42$ & $1.07 \pm 0.10$ & 1.61 & $1.82 \pm 0.34$ & $1.08 \pm 0.24$ & 0.74 \\
\hline C. glacialis & - & 0.23 & $0.43 \pm 0.23$ & - & $0.17 \pm 0.08$ & $0.47 \pm 0.17$ & 0.24 \\
\hline Metridia sp. & 1.43 & $0.71 \pm 0.02$ & $0.68 \pm 0.16$ & 1.68 & $1.64 \pm 0.38$ & $1.35 \pm 0.39$ & 0.22 \\
\hline Centropages spp. & - & - & $2.76 \pm 0.49$ & - & 0.06 & $3.77 \pm 1.36$ & 3.22 \\
\hline Acartia tonsa & 0.19 & $0.51 \pm 0.40$ & $2.02 \pm 0.75$ & - & $4.08 \pm 1.88$ & $4.39 \pm 3.28$ & 2.26 \\
\hline Pseudocalanus sp. & - & - & - & - & - & - & - \\
\hline \multirow[t]{3}{*}{ Euchaeta sp. } & 2.24 & $0.72 \pm 0.14$ & $0.41 \pm 0.14$ & 0.15 & $0.85 \pm 0.19$ & $0.77 \pm 0.37$ & - \\
\hline & & - North & & & - South - & & Other \\
\hline & July (4) & Aug (4) & Sept (2) & July (3) & Aug (6) & Sept (2) & Sept (4) \\
\hline \multicolumn{8}{|l|}{2007} \\
\hline C. finmarchicus (V) & $56.32 \pm 5.78$ & $77.71 \pm 3.51$ & $80.67 \pm 2.95$ & $65.62 \pm 2.56$ & $72.82 \pm 2.57$ & $87.76 \pm 0.08$ & $67.77 \pm 6.35$ \\
\hline C. finmarchicus (adult) & $10.89 \pm 1.12$ & $6.34 \pm 0.85$ & $7.07 \pm 1.41$ & $7.35 \pm 1.35$ & $8.61 \pm 0.95$ & $5.32 \pm 1.14$ & $12.93 \pm 2.36$ \\
\hline C. finmarchicus (IV) & $10.15 \pm 6.51$ & $0.18 \pm 0.03$ & 0.25 & $11.61 \pm 6.45$ & $1.20 \pm 0.52$ & $0.07 \pm 0.02$ & $1.41 \pm 1.01$ \\
\hline C. finmarchicus (III) & $1.56 \pm 1.33$ & 0.07 & 0.05 & $0.94 \pm 0.03$ & $0.37 \pm 0.13$ & 0.08 & 0.56 \\
\hline C. hyperboreous & $2.75 \pm 0.72$ & $2.57 \pm 0.63$ & $3.35 \pm 1.07$ & $1.56 \pm 1.08$ & $2.53 \pm 0.38$ & $1.12 \pm 0.44$ & $1.28 \pm 0.49$ \\
\hline C. glacialis & $8.27 \pm 2.63$ & $8.80 \pm 1.66$ & $5.09 \pm 2.72$ & $4.68 \pm 1.25$ & $6.97 \pm 0.54$ & $3.87 \pm 0.98$ & $5.19 \pm 1.89$ \\
\hline Metridia sp. & $2.45 \pm 0.52$ & $1.56 \pm 0.53$ & $1.34 \pm 0.58$ & $1.68 \pm 0.56$ & $1.28 \pm 0.24$ & $0.53 \pm 0.23$ & $2.22 \pm 1.20$ \\
\hline Centropages spp. & - & - & - & - & - & - & $1.84 \pm 0.54$ \\
\hline Acartia tonsa & $7.58 \pm 0.43$ & $1.92 \pm 0.66$ & $1.45 \pm 0.22$ & $6.56 \pm 1.46$ & $5.95 \pm 1.79$ & $1.01 \pm 0.56$ & $7.85 \pm 2.11$ \\
\hline Pseudocalanus sp. & 0.30 & 1.02 & 1.70 .04 & -0.1 .40 & - & $1.01-0$ & - \\
\hline Euchaeta sp. & $0.47 \pm 0.24$ & $0.87 \pm 0.37$ & $0.87 \pm 0.09$ & $0.32 \pm 0.08$ & $0.41 \pm 0.23$ & $0.28 \pm 0.19$ & $0.49 \pm 0.08$ \\
\hline
\end{tabular}
conducted at each station 
nificant differences in C5 proportion between sampling stations or months. In 2007, there was an increasing trend in C5 proportion from July to September ( $\mathrm{p}<0.001)$; however, there were no significant differences between August and September (Table 1). Other species present included C. hyperboreus, C. glacialis, Acartia tonsa and Metridia. Of these species, C. glacialis and A. tonsa showed the most annual variability with increased proportions from 2006 to 2007 (Table 1). Larger zooplankton consisted of euphausiids, pandalids, chaetognaths and cnidarians, however these species were infrequent and represented less than $0.1 \%$ of the individuals in a tow.

\section{Lipid content and composition of copepods}

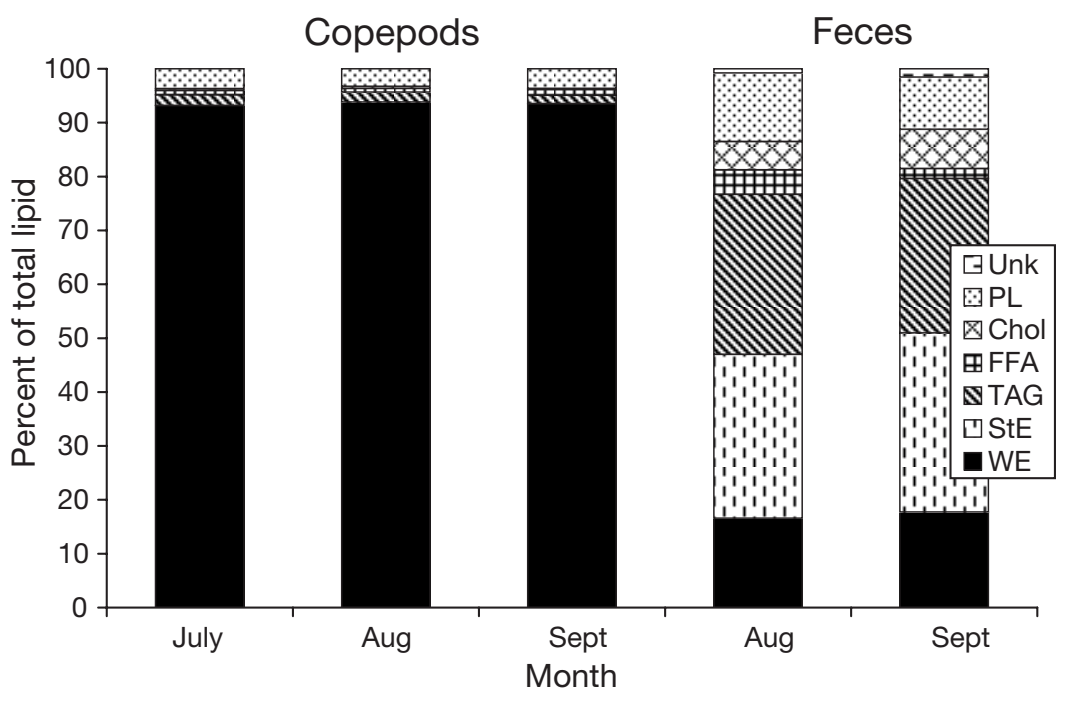

Fig. 3. Mean copepod Calanus finmarchicus and right whale fecal lipid class composition (\% of total lipids) from samples collected in 2006 and 2007 from the northern and southern stations. WE: wax ester; StE: sterol ester; TAG: triacylglycerol; FFA: free fatty acid; Chol: cholesterol; PL: phospholipid; Unk: unknown components

As copepods dominated the zooplankton, we refer hereafter to the lipid composition of the 'copepods,' even though there were small numbers of other small zooplankton present in the tows; however, right whales are ingesting all of these smaller organisms as well, so they form part of the lipid content of the diet and are included here. Copepod lipid content averaged $7.17 \% \pm 0.14 \mathrm{wt} \%$ (wet weight) in all tows during $2006(\mathrm{n}=37)$ and 2007 $(\mathrm{n}=27)$. Although there was a wide range in lipid content (4.55 to $9.91 \mathrm{wt} \%$ ), there were no significant differences across months, years or sampling sites (Fig. 2).

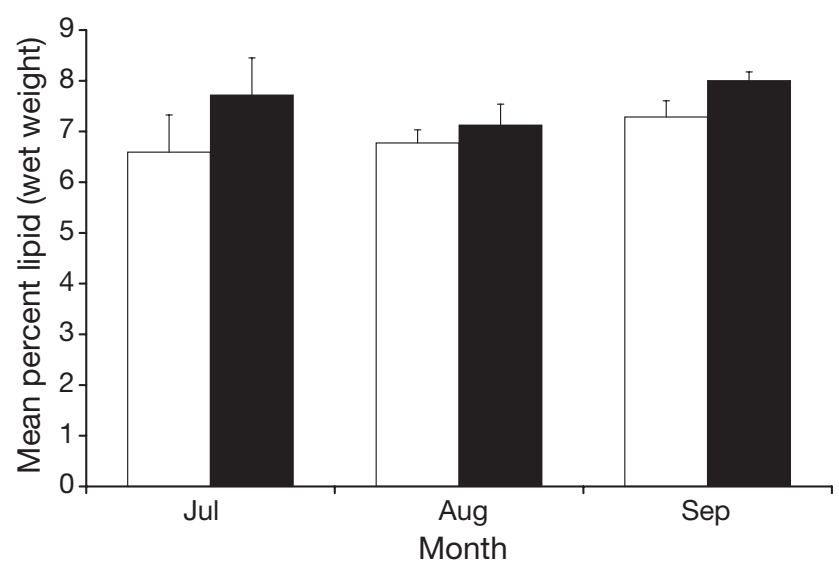

Fig. 2. Calanus finmarchicus. Mean \pm SE copepod lipid content values (wet weight) from zooplankton samples collected in 2006 and 2007 from the northern (white bars) and southern (black bars) stations

The dominant lipid class present among all copepod samples was WE, followed by PL, TAG, free fatty acid (FFA), and Chol (Fig. 3). There was little monthly variation in lipid class composition in samples collected in either 2006 or 2007. On average, copepod lipid content was $93.75 \pm 0.30 \% \mathrm{WE}$ and showed no significant differences in WE content across months, years or sampling sites. PL ranged from approximately 2 to $5 \%$ (mean 3.56\%) from samples collected in 2006 and 2007, however there were no significant spatial or temporal differences observed. Mean TAG content was $1.52 \pm 0.07 \%$ and, although there was a slight decrease in TAG from July to September 2007 from approximately 2.0 to $1.5 \%$, there were no significant spatial or temporal differences in TAG components. FFA and Chol averaged $<1.0 \%$ for all samples collected and showed no significant differences across sampling month, year or location. GCMS confirmed the absence of StE in copepods.

Copepod samples collected throughout the Bay of Fundy in 2006 and 2007 consisted primarily of longchain FA and FAlc. Specifically, 14:0 and 16:0 were the dominate FA components in all copepod samples, with monounsaturated and polyunsaturated components $16: 1 \mathrm{n}-7,18: 1 \mathrm{n}-9,20: 1 \mathrm{n}-9,22: 1 \mathrm{n}-11$ and $18: 4 \mathrm{n}-3$, $20: 5 n-3,22: 6 n-3$ comprising the majority of the remaining FA (Table 2, Fig. 4a,c). The long-chained monounsaturates 20:1n-9 and 22:1n-11 dominated the FAlc composition, at 10 to $12 \mathrm{wt} \%$ of the total lipid, followed by the 16:0 and 22:1n-9 FAlc components (Table 2). 
Table 2. Mean \pm SE fatty acid and fatty alcohol composition (wt \%) of copepods (2006: 38 tows; $2007: 26$ tows) and fecal samples (2006: 17; 2007: 7). Although 66 fatty acids (FA) and 11 fatty alcohols (FAlc) were identified, only components representing $>0.1 \mathrm{wt} \%$ are shown. (-: component not detected or present at $<0.1 \%$ ). Sterol and anteiso and iso values are sums of all components

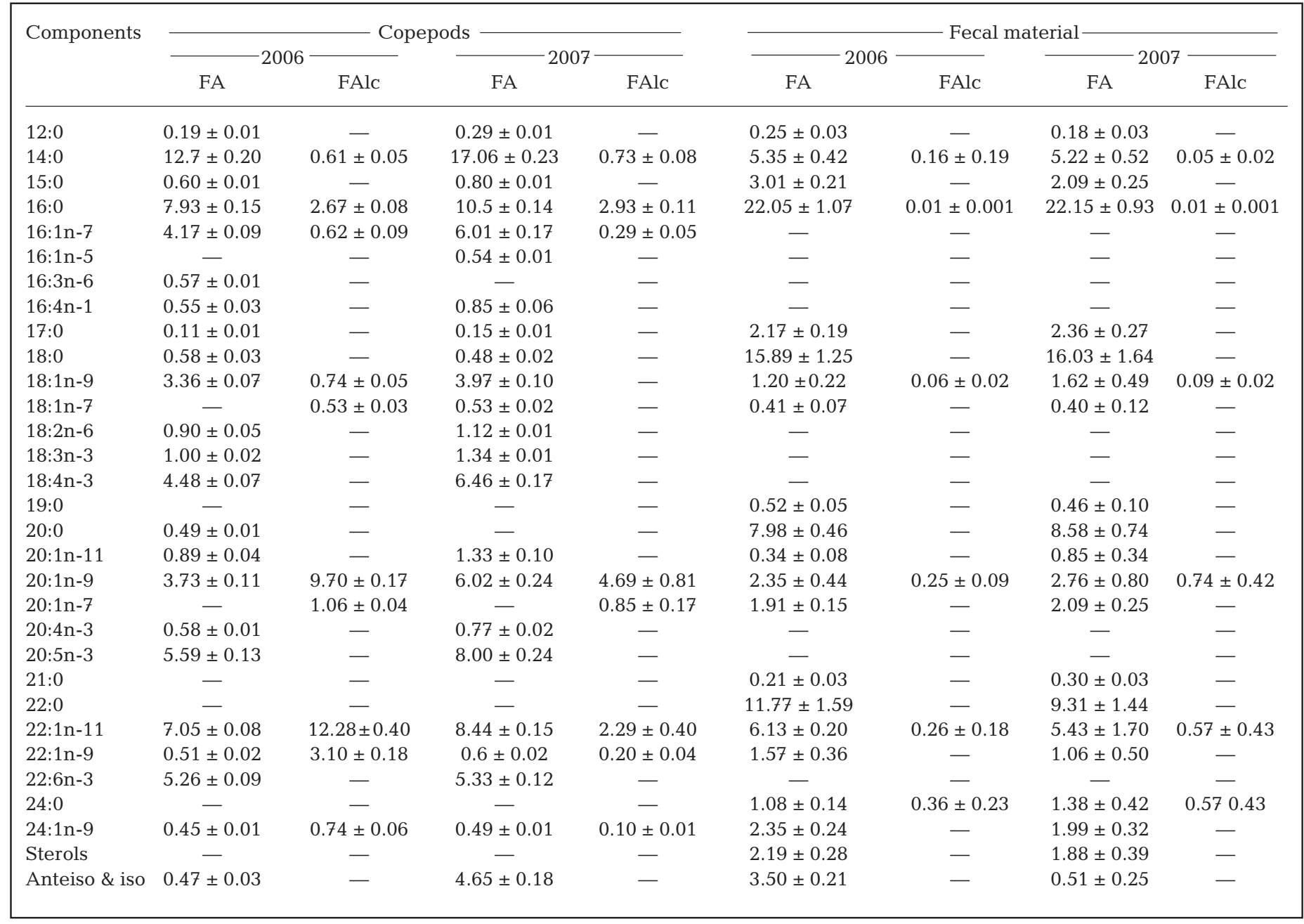

\section{Lipid content and composition of right whale feces}

In 2006 and 2007, right whale fecal lipid percentages averaged $2.48 \pm 0.43 \mathrm{wt} \%$ and $4.29 \pm 0.39 \mathrm{wt} \%$ and ranged between 0.9 and $8.6 \mathrm{wt} \%$. There were no significant differences in fecal lipid percentages between sampling months in 2006 and 2007, however fecal lipids were significantly higher in 2007 ( $p=0.020)$.

The dominant lipid classes present in all fecal samples collected in 2006 and 2007 were TAG and StE, followed by WE, PL, Chol, FFA and unknown lipid components (Fig. 3). Across all samples, mean estimated TAG and StE lipid class composition were $29.17 \pm$ $2.48 \mathrm{wt} \%$ and $31.34 \pm 2.75 \mathrm{wt} \%$, respectively, and showed no significant differences in fecal lipid class content between sampling months or years. Similarly, fecal WE composition at $16.92 \pm 3.40 \%$ (wet weight) showed no annual or monthly differences.
Right whale fecal composition was dominated by saturated FA components (Fig. 4b,d), consisting primarily of $14: 0,15: 0,16: 0,17: 0,18: 0,20: 0,22: 0$ and 24:0 (Table 2). Monounsaturated FA 18:1, 20:1, 22:1, 22:1 and 24:1 comprised the majority of the FA remaining in the feces. Fatty alcohol, sterol, anteiso (ai-) and iso ( $i-$ ) components each represented $<1.0 \%$ wet weight of the fecal composition (Fig. 4b,d). Unlike the copepods, there were no polyunsaturated fatty acids observed in the fecal material (Table 2, Fig. 4).

The overall FA and FAlc compositions of the copepods and feces were very different. The DFA showed Wilks' Lambda to be significant ( $p<0.001)$, indicating that the 2 types of samples could be distinguished based on their lipid composition. Because only 2 groups were used, the DFA yielded a single DF. Classification based on DF scores resulted in all cases being correctly assigned. Validation using a leave- 


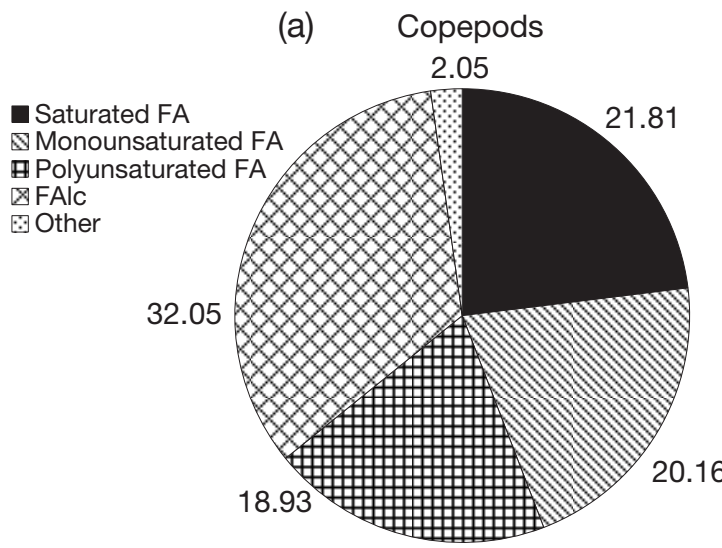

(b)
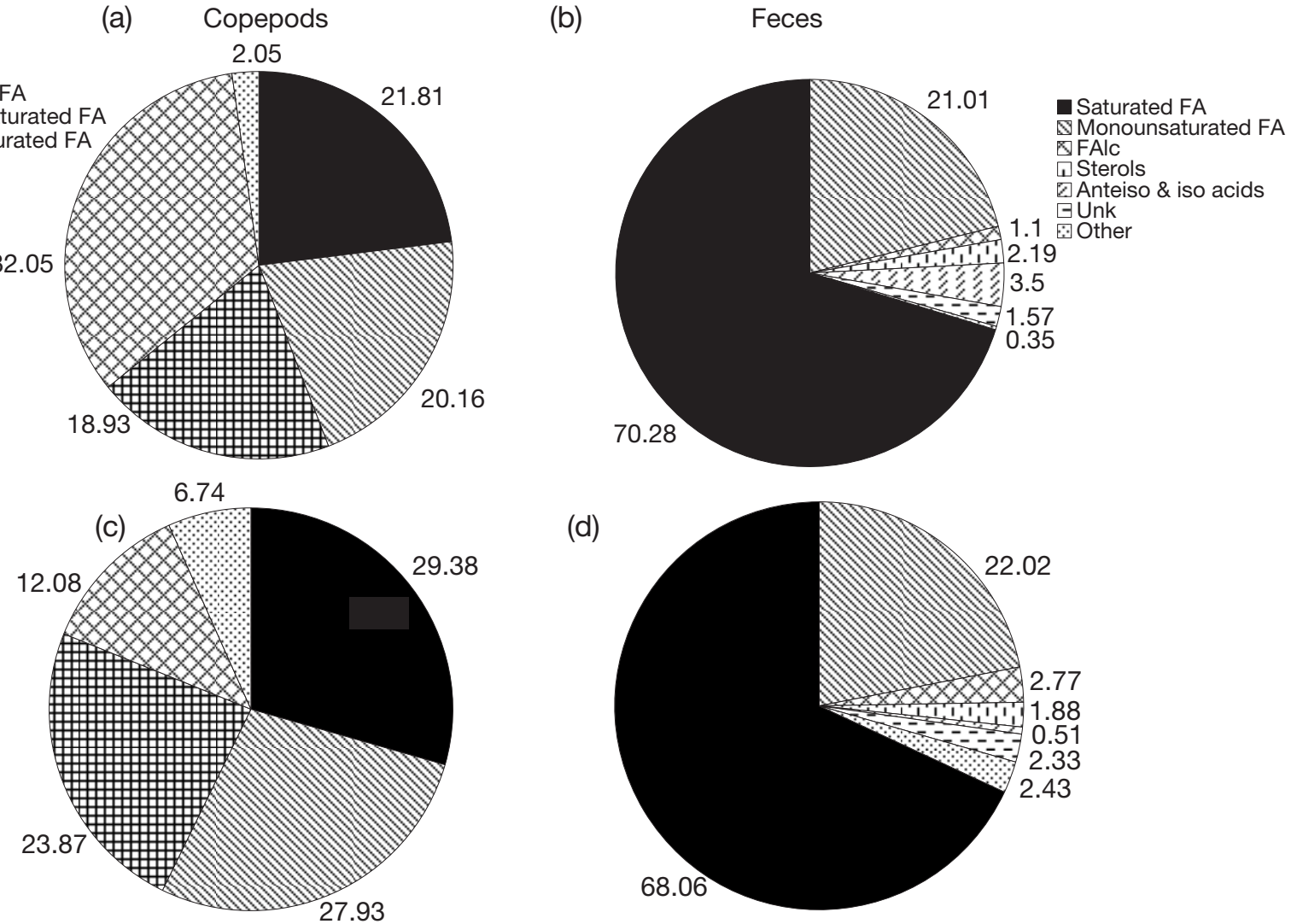

(d)

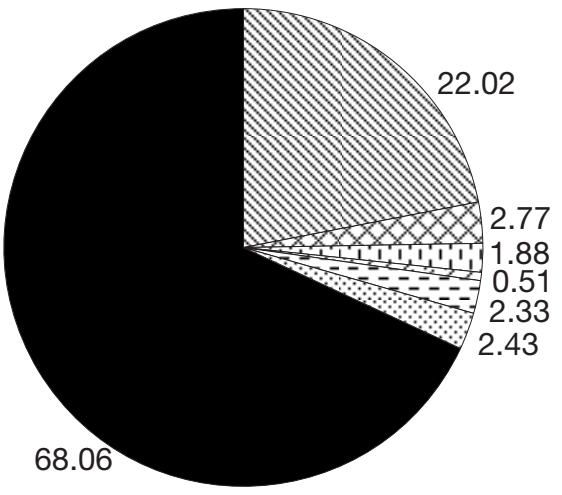

Fig. 4. Calanus finmarchicus and Eubalaena glacialis. Mean saturated, monounsaturated, polyunsaturated fatty acids (FA) and fatty alcohols (FAlc), sterols, anteiso and iso acids, unknown (unk) and other lipid components from $(\mathrm{a}, \mathrm{c})$ copepods and (b,d) right whale fecal material collected in (a,b) 2006 and (c,d) 2007

one-out approach also resulted in $100 \%$ correct reclassification.

\section{Modeling lipid assimilation}

A mean C5 concentration of $7481 \mathrm{~m}^{-3}$ (Baumgartner \& Mate 2003) was used in the ingestion rate model. Using Eq. (1), $I_{\mathrm{d}}$ was estimated to be 586570248 C5 copepods $\mathrm{d}^{-1}$. From Eq. (2), total grams ingested $\left(I_{\mathrm{g}}\right)$

Table 3. Eubalaena glacialis. Mean lipid classes ingested and eliminated $\left(\mathrm{g} \mathrm{d}^{-1}\right)$ by the average $40000 \mathrm{~kg}$ right whale, based on mean percent copepod and fecal lipid class values (wt\%). Abbreviations as in Fig. 3

\begin{tabular}{|lccccccccc|}
\hline$\%$ lipid & Lipid ingested $(\mathrm{g}) \mathrm{d}^{-1}$ & WE & StE & TAG & FFA & Chol & PL & Unk \\
\hline 7.2 & $\begin{array}{c}61824 \\
3.0\end{array}$ & 58013 & ND & 1036 & 494 & 87 & 2194 & ND \\
& $\begin{array}{c}\text { Feces eliminated }(\mathrm{g}) \mathrm{d}^{-1} \\
1570\end{array}$ & 248 & 515 & 461 & 61 & 86 & 182 & 17 \\
& $\begin{array}{c}\text { Lipid assimilated }(\mathrm{g}) \mathrm{d}^{-1} \\
60786\end{array}$ & 57765 & - & 575 & 433 & 1 & 2012 & - \\
\hline
\end{tabular}

was estimated to be $862258 \mathrm{~g} \mathrm{C} \mathrm{d}^{-1}$. Assuming a mean C5 percent lipid of $7.17 \%$ and Eq. (3), total lipid ingested $\left(I_{\mathrm{L}}\right)$ was estimated as $61824 \mathrm{~g}$ lipid $\mathrm{d}^{-1}$ (Table 3). WE was the dominant lipid component ingested by right whales (mean $58013 \mathrm{~g}$ ) (Table 3).

Using Eq. (5), a $40000 \mathrm{~kg}$ right whale was estimated to eliminate $52326 \mathrm{~g}_{\text {feces }} \mathrm{d}^{-1}$. Based on these data and mean fecal lipid content (3.0\%), it was estimated that a right whale would eliminate $1570 \mathrm{~g}$ lipid d $\mathrm{d}^{-1}$ (Table 3). TAG and StE were the dominant lipid classes found in the feces (Fig. 3, Table 3), comprising $29 \%$ and $33 \%$, respectively, of the total fecal lipid. PL and WE components comprised $12 \%$ and $16 \%$, respectively, of the eliminated lipid. The other lipid components combined represented approximately $10 \%$ of the total lipid eliminated (Table 3). Thus the average right whale eliminates $248 \mathrm{~g}$ of WE $\mathrm{d}^{-1}$.

Total daily assimilation of copepods was estimated as $809932 \mathrm{~g} \mathrm{~d}^{-1}$. Grams 


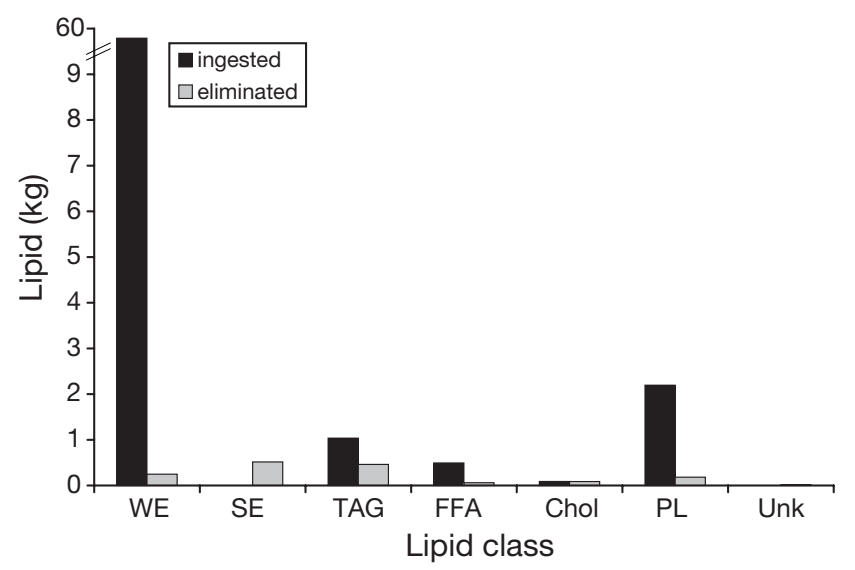

Fig. 5. Eubalaena glacialis. Lipid class ingestion and elimination rates $\left(\mathrm{kg} \mathrm{d}^{-1}\right)$ as estimated for right whales. Abbreviations as in Fig. 3

of lipid assimilated $\mathrm{d}^{-1}$ was estimated as $60786 \mathrm{~g} \mathrm{~d}^{-1}$ (Table 3). Daily WE assimilation was estimated at 57765 $\mathrm{g} \mathrm{d}^{-1}$, followed by PL and TAG components at $2012 \mathrm{~g}$ $\mathrm{d}^{-1}$ and $575 \mathrm{~g} \mathrm{~d}^{-1}$ (Table 3 ). These data represent a total (mass-based) assimilation efficiency of $94 \%$, a lipid assimilation efficiency of $98 \%$ and WE assimilation efficiency greater than $99 \%$ (Fig. 5).

\section{DISCUSSION}

\section{WE metabolism}

WE are the dominant lipid present in the copepod prey but are present in extremely small quantities in right whale fecal material. These data, along with low overall lipid content in right whale feces, demonstrate that right whales are able to assimilate the WE components of the copepods they ingest. FA and FAlc analyses further validate WE assimilation in right whales, and the disparity between copepod and fecal lipids indicates that the majority of the lipid components in the feces are not of dietary origin (see below).

Although WE in marine environments have been studied for several decades (see Lee et al. 2006, Kattner et al. 2007), the role of WE as an energy store, particular when utilized by mammals, is unclear. TAG can be rapidly metabolized by all animals and thus are the primary form of ingested and stored lipids in all mammals (Pond 1998). Evidence from in vitro and in vivo studies indicates that most animals, mammals in particular, are extremely inefficient at metabolizing waxes, as they hydrolyze WE at only about one-tenth the rate that TAG can be broken down (Savory 1971, Patton \& Benson 1975, Sargent 1976, Place 1992a).
Mammals are thought to have a WE assimilation efficiency of $<50 \%$ (Hansen \& Mead 1965, Place 1992a).

To date the only other study that has examined WE digestion in cetaceans was by Nordøy (1995). His analysis examined the lipid components of fresh undigested forestomach and colon contents obtained from dead whales and previously determined in vitro digestibility estimates of krill (Nordøy et al. 1993). Our approach was slightly different and relied on the direct comparison of WE present in right whale prey and in the feces of living whales. Interestingly, both studies revealed similar results, with WE assimilation efficiencies $>90 \%$. It would appear that baleen whales that rely on a WE-rich diet have overcome the digestive limitations of most terrestrial mammals and are able to utilize WE efficiently.

Several mechanisms to digest WE have been postulated, including bile-activated lipase and increased gut retention time via a pyloric caeca (Patton \& Benson 1975, Place 1992b). Friedmann \& Kern (1956) first suggested that the lesser honeyguide Indicator minor contains a symbiotic gut microorganism to help break down WE. Downs et al. (2002) later analyzed the microbial fauna in the honeyguide's gastrointestinal cavity using enzymatic assays and found no microbial activity in the same species; instead they suggested that a decreased gut passage rate increases the time that digesta are in contact with enzymes. Several delphinid species of the genus Stenella and other whale species (minke, sperm whales Physeter macrocephalus and bowheads Balaena mysticetus) eat WE-rich prey (Gaskin 1982); however, little work has been done to investigate the digestive capabilities of these cetaceans. Several studies have examined microbial activity in forestomachs of minke (Nordøy et al. 1993, Olsen et al. 1994, 2000, Nordøy 1995), bowhead, gray whales Eschrichtius robustus (Herwig et al. 1984) and fin whales Balaenoptera physalus (Herwig \& Staley 1986). These studies report high microbial activity in the forestomach, suggesting that the multi-chambered stomach may act as a fermentation center, extending digesta retention times. Olsen et al. (2000) reported that the forestomach of minke whales contain chinolytic bacteria that are capable of breaking down the chitinous shell (indigestible in most mammals) of their crustacean prey (krill). Although many studies have reported evidence of WE assimilation by several different species, there remains a lack of direct evidence of the mechanisms that may allow efficient WE assimilation. It is likely that different taxa utilize different mechanisms to accomplish this goal. This is an area of research worthy of further investigation.

The lipid composition of right whale feces did not reflect the lipid composition of the copepods or that of typical mammalian endogenous lipids. In fact, there 
was no overlap at all between FA and FAlc signatures of copepods and feces, as demonstrated by DFA. The fecal composition consisted of $>60 \%$ saturated FA components (Fig. 4b,d), 5 of which were not found in any significant quantities in the copepods (Table 2). The origin of the saturated lipid components found in the feces of right whales is unknown. It is unlikely that right whales would selectively ignore saturated components of dietary origin, as they are easily broken down for metabolism or lipid storage and represent considerable energy stores. The large proportion of saturated FA in the feces suggests that they may originate in the gut, however their exact mechanism of synthesis is still unclear. Mammals typically synthesize fatty acids 16:0, 18:0, 16:1 and 18:1, but not 20:0, 22:0 and 24:0 (Iverson 1993). Bacterial organisms, however, can produce longer saturated FA components, including 20:0, 22:0 and 24:0 (O'Leary 1962). The presence of a gut microorganism capable of digesting WE would represent an unusual mammalian physiological adaptation allowing right whales to take advantage of an abundant energy resource.

\section{Lipid content and composition of copepods}

In our study, WE dominated copepod lipid composition in the Bay of Fundy, comprising $94 \%$ of the total lipid present. Michaud \& Taggart (2007) reported that WE content in copepods in the Grand Manan Basin reaches a maximum of $75 \%$, which is considerably lower than reported by this study and others from higher latitudes (Kattner \& Krause 1987, Kattner \& Graeve 1991, Kattner \& Hagen 1995). Copepod lipid content and WE proportions typically decreases with decreasing latitude (Kattner 1989); however, we found WE values $(\sim 90 \%)$ closer to those found in polar regions (Kattner \& Krause 1987, Kattner \& Graeve 1991, Kattner \& Hagen 1995). There was no variation in lipid composition between sampling sites within or outside of our selected region, indicating that copepod lipid composition did not vary spatially over the course of this study in the areas in which whales are most often observed feeding.

\section{Validation of assimilation models}

The estimated assimilation rates of right whales were constrained by the inherent assumptions and caveats of the models used. Assimilation models are subject to variation in parameter estimation (e.g. individual animals, gape size, swim speed, dive duration, copepod concentration) and may significantly affect assimilation estimates by either overestimating or underestimating ingestion rates. Although our estimates are based on the best available data of right whale feeding behavior and food availability, these variables are only mean values and do not capture the full range of variability. In spite of these caveats, our estimates are supported by other work investigating metabolic requirements of large baleen whales.

To determine whether the assimilation estimates are reasonable, values presented here were compared with estimated daily energetic requirements of right whales. Kenney et al. (1986) reported that in order to meet basal metabolic requirements, a $40000 \mathrm{~kg}$ right whale must ingest 600 to $1600 \mathrm{~kg}$ of zooplankton $\mathrm{d}^{-1}$. These ingestion estimates were based on consumption rates of 1.5 to $4.0 \%$ of body weight $d^{-1}$ (Sergeant 1969, Lockyer 1981a). Baumgartner \& Mate (2003) reported C5 densities of $7481 \mathrm{C}^{-3} \mathrm{~m}^{-3}$ that could meet the energetic demands predicted by Kenney et al. (1986); when applied to the assimilation model from the current study, this suggests an ingestion rate of $2.2 \%\left(862258 \mathrm{~g} \mathrm{C}^{-1} \mathrm{~d}^{-1}\right)$. Although within the range of ingestion rates estimated for baleen whales (Sergeant 1969, Lockyer 1981b) it likely still underestimates the daily feeding rate.

We recognize that the generalized defecation model we have used does not allow for any variability in fecal production based on feeding rates (i.e. if a whale eats twice as many copepods, presumably it generates twice as much fecal material). However, the lipid content of the feces is so low that significant changes in fecal production do not translate into major differences in our estimates of WE assimilation efficiencies. For example, a doubling of daily fecal production (to $496 \mathrm{~g}$ of WE) still leads to a WE assimilation rate of $>99 \%$, and even a ten-fold increase in fecal production only causes our estimates of WE assimilation to drop to $96 \%$. We also recognize that we may not be capturing all components of the fecal material, as portions of it may sink prior to collection. However, given that lipids are buoyant in seawater, it is likely that we are able to collect the majority of the lipid portion of the feces. Even if some of the more dense, non-lipid material sinks, our data will have resulted in an overestimate of the lipid content in feces (already quite low, as mentioned above), which means whales would be capable of digesting an even greater fraction of ingested waxes. Thus we are confident that our estimate serves as a reasonable illustration of exactly how capable these animals are at metabolizing WE.

\section{Energetic significance}

The overall low lipid content and the relative absence of FAlc in right whale fecal material suggest that right whales are highly efficient at metabolizing 
the vast majority of the lipids present in their diet. The models we applied further support high lipid assimilation efficiencies in right whales. Applying Baumgartner \& Mate's (2003) mean C5 density of $7481 \mathrm{~m}^{-3}$ to the assimilation model, right whale total assimilation efficiency is approximately $92 \%$ (Table 3), and lipid assimilation efficiencies are much higher at 98\% (Table 3). Assimilation efficiencies in other marine mammals, such as the Northern fur seal Callorhinus ursinus (Fadely et al. 1990), are thought to be high, at $>90 \%$ (Lockyer 2007), and Lockyer (1981b) estimated an assimilation efficiency of $80 \%$ for baleen mammals in general. Metabolically, it appears as though right whales are efficiently metabolizing the majority of the lipid from their diet; however, the absolute amount of lipid available may be a more important factor associated with whales meeting energetic requirements.

Our results validate current right whale energetic and foraging models that rely on the assumption that these animals are able to metabolize all of the lipids in their diet. The data presented here can therefore be used to further refine models of habitat quality (in terms of the nutritional value of the prey base) for right whales, and in turn aid in the creation of management strategies aimed at protecting critical habitat for these animals. This study also emphasizes the importance of monitoring food quality and availability in predictable foraging areas such as the lower Bay of Fundy, as fluctuations in both C5 Calanus finmarchicus densities and energetic value may affect the success of this struggling North Atlantic population.

Acknowledgements. We thank the following, without whom this project would not have been possible: NEAq field research teams working on the RV 'Nereid' for collecting fecal samples; M. Brown, P. Hamilton and the North Atlantic Right Whale Consortium for their feedback and providing right whale sightings data; and L. Murison, W. McLellan and the members of the GMWSRS who provided assistance with this project. We also thank S. Budge (Dalhousie University, Halifax, Nova Scotia) for carrying out the GCMS identification of the FA and FAlc components. Funding from UNCW, Sigma Xi, CWI, Fairmount Algonquin Hotel and GMWSRS supported this study. Funding for fecal sample collection was provided by NOAA/NMFS Contract \# DG133F04CN0056 (to R.M.R.), and for right whale Bay of Fundy surveys (to NEAq) by NMFS Right Whale Research Program Grant \#: NAO3NMF4720476, Irving Oil, WWF-Canada, Environment Canada, International Fund for Animal Welfare, and the Island Foundation. Research in the Bay of Fundy was conducted in accordance with institutional, national and international guidelines concerning the sampling of endangered species, under Canadian Species at Risk Act, Scientific Research Permits \# MAR-SA-2006-007, MAR-SA-2007-007. Zooplankton were collected in the Bay of Fundy under Department of Fisheries and Oceans Canada permits 2006527 and 2007-501. The authors acknowledge use of the Maptool program for creating the map in this paper. Maptool is a product of SEATURTLE.ORG (information is available at www.seaturtle.org).

\section{LITERATURE CITED}

Ackman R, McLeod C, Banerjee A (1990) An overview of analyses by chromarod-iatroscan TLC-FID. J Planar Chromatogr Mod TLC 3:450-490

Baumgartner MF (2003) Comparisons of Calanus finmarchicus fifth copepodite abundance estimates from nets and an optical plankton counter. J Plankton Res 25:855-868

Baumgartner MF, Mate BR (2003) Summertime foraging ecology of North Atlantic right whales. Mar Ecol Prog Ser 264:123-135

- Baumgartner MF, Cole TVN, Campbell RG, Teegarden GJ, Durbin EG (2003) Associations between North Atlantic right whales and their prey, Calanus finmarchicus, over diel and tidal time scales. Mar Ecol Prog Ser 264:155-166

Baumgartner MF, Mayo CA, Kenney RD (2007) Enormous carnivores, microscopic food, and a restaurant that's hard to find. In: Kraus SD, Rolland RM (eds) The urban whale: North Atlantic right whales at the crossroads. Harvard University Press, Cambridge, MA, p 138-171

Blueweiss L, Fox H, Kudzma V, Nakashima D, Peters R, Sams S (1978) Relationships between body size and some life history parameters. Oecologia 37:257-272

Caswell H, Fujiwara M, Brault S (1999) Declining survival probability threatens the North Atlantic right whale. Proc Natl Acad Sci USA 96:3308-3313

Clapham PJ, Young SB, Brownell RL (1999) Baleen whales: conservation issues and the status of the most endangered populations. Mammal Rev 29:37-60

Comita GW, Marshall SM, Orr AP (1966) On the biology of Calanus finmarchicus XIII. Seasonal change in weight, calorific value and organic matter. J Mar Biol Assoc UK 46:1-17

Downs CT, van Dyk RJ, Iji P (2002) Wax digestion by the lesser honeyguide Indicator minor. Comp Biochem Physiol A 133:125-134

> Duncan RP, Forsyth DM, Hone J (2007) Testing the metabolic theory of ecology: allometric scaling exponents in mammals. Ecology 88:324-333

Fadely BS, Worthy GJ, Costa DP (1990) Assimilation efficiency of northern fur seals determined using dietary manganese. J Wildl Manage 54:246-251

> Folch J, Lees M, Sloane Stanley GH (1957) A simple method for the isolation and purification of total lipides from animal tissues. J Biol Chem 226:497-509

- Friedmann H, Kern J (1956) The problem of cerophagy or wax-eating in the honeyguides. Q Rev Biol 31:19-30

> Fujiwara M, Caswell H (2001) Demography of the endangered North Atlantic right whale. Nature 414:537-541

Gaskin DE (1982) The ecology of whales and dolphins. Heinemann, London

Gosner KL (1971) Guide to identification of marine and estuarine invertebrates. Cape Hatteras to the Bay of Fundy. Wiley-Interscience, New York

Hamilton RJ (1995) Waxes: chemistry, molecular biology and functions, Vol 6. The Oily Press, Dundee

> Hansen IA, Mead JM (1965) The fate of dietary wax esters in the rat. Proc Soc Exp Biol Med 120:527-532

$>$ Herwig RP, Staley JT (1986) Anaerobic bacteria from the digestive tract of North Atlantic fin whales (Balaenoptera physalus). FEMS Microbiol Ecol 38:361-371

- Herwig RP, Staley JT, Nerini MK, Braham HW (1984) Baleen whales: preliminary evidence for forestomach microbial fermentation. Appl Environ Microbiol 47:421-423

Iverson SJ (1993) Milk secretion in marine mammals in relation to foraging: Can milk fatty acids predict diet? Symp Zool Soc Lond 66:263-291 
Iverson SJ, Frost KJ, Lowry LF (1997) Fatty acid signatures reveal fine scale structure of foraging distribution of harbor seals and their prey in Prince William Sound, Alaska. Mar Ecol Prog Ser 151:255-271

Iverson SJ, Frost KJ, Lang SLC (2002) Fat content and fatty acid composition of forage fish and invertebrates in Prince William Sound, Alaska: factors contributing to among and within species variability. Mar Ecol Prog Ser 241:161-181

Jacob J (1982) Avian biology, Vol 6. Academic Press, London

Johnson JJ, Kraus SD, Kenney JF, Mayo CA (2007) The entangled lives of right whales and fishermen: Can they coexist? In: Kraus SD, Rolland RM (eds) The urban whale: North Atlantic right whales at the crossroads. Harvard University Press, Cambridge, MA, p 380-408

Kattner G (1989) Lipid composition of Calanus finmarchicus from the North Sea and the Arctic. A comparative study. Comp Biochem Physiol B 94:185-188

Kattner G, Graeve M (1991) Wax ester composition of dominant calanoid copepods of the Greenland Sea/Fram Strait region. Polar Res 10:479-485

Kattner G, Hagen W (1995) Polar herbivorous copepods-different pathways in lipid biosynthesis. ICES J Mar Sci 52:329-335

Kattner G, Krause M (1987) Changes in lipids during the development of Calanus finmarchicus s.l. from copepodid I to adult. Mar Biol 96:511-518

Kattner G, Hagen W, Lee RF, Campbell R and others (2007) Perspectives on marine zooplankton lipids. Can J Fish Aquat Sci 64:1628-1639

Kenney RD, Hyman MAM, Owen RE, Scott GP, Winn HE (1986) Estimation of prey densities required by western North Atlantic right whales. Mar Mamm Sci 2:1-13

Knowlton AR, Brown MB (2007) Running the gauntlet: right whales and vessel strikes. In: Kraus SD, Rolland RM (eds) The urban whale: North Atlantic right whales at the crossroads. Harvard University Press, Cambridge, MA, p 409-435

Knowlton AR, Kraus SD (2001) Mortality and serious injury of northern right whales (Eubalaena glacialis) in the Western North Atlantic Ocean. J Cetacean Res Manag 2(Spec Iss): 193-208

Koopman HN, Iverson SJ, Gaskin DE (1996) Stratification and age-related differences in blubber fatty acids of the male harbour porpoise (Phocoena phocoena). J Comp Physiol B 165:628-639

Koopman HN, Budge SM, Ketten DR, Iverson SJ (2006) Topographical distribution of lipids inside the mandibular fat bodies of odontocetes: remarkable complexity and consistency. IEEE J Oceanic Eng 31:95-106

Kraus SD, Rolland RM (2007) Right whales in the urban ocean. In: Kraus SD, Rolland RM (eds) The urban whale: North Atlantic right whales at the crossroads. Harvard University Press, Cambridge, MA, p 1-38

Kraus SD, Hamilton PK, Kenney RD, Knowlton AR, Slay CK (2001) Reproductive parameters of the North Atlantic right whale. J Cetacean Res Manag 2(Spec Iss):231-236

Kraus SD, Pace RM III, Frasier TR (2007) High investment, low return: the strange case of reproduction in Eubalaena glacialis. In: Kraus SD, Rolland RM (eds) The urban whale: North Atlantic right whales at the crossroads. Harvard University Press, Cambridge, MA, p 172-199

Lavigne DM (1982) Similarity in energy budgets of animal populations. J Anim Ecol 51:195-206

Lee RF, Hagen W, Kattner G (2006) Lipid storage in marine zooplankton. Mar Ecol Prog Ser 307:273-306

Lockyer C (1981a) Estimation of the energy costs of growth, maintenance and reproduction in the female minke whale
(Balaenoptera acutorostrata), from the Southern Hemisphere. Rep Int Whal Comm 31:337-343

Lockyer C (1981b) Growth and energy budgets of large baleen whales from the southern hemisphere. In: FAO Advisory Committee on Marine Resource Research (ed) Mammals in the sea, Vol 3. General papers and large cetaceans. FAO, Rome, p 379-487

Lockyer C (2007) All creatures great and smaller: a study in cetacean life history energetics. J Mar Biol Assoc UK 87: $1035-1045$

Mankura M, Kayama M, Saito H (1984) Wax ester hydrolysis by lipolytic enzymes in pyloric caeca of various fishes. Bull Jpn Soc Sci Fish 50:2127-2131

Mayo CA, Letcher BH, Scott S (2001) Zooplankton filtering efficiency of the baleen of a North Atlantic right whale, Eubalaena glacialis, and associated zooplankton characteristics. J Cetacean Res Manag 2(Spec Iss):225-229

> McKey DB, Gartlan JS, Waterman PG, Choo GM (1981) Food selection by black colobus monkeys (Colobus satanas) in relation to plant chemisty. Biol J Linn Soc 16:115-146

McNab BK (2002) The physiological ecology of vertebrates: a view from energetics. Cornell University Press, New York

> Michaud J, Taggart CT (2007) Lipid and gross energy content of North Atlantic right whale food, Calanus finmarchicus, in the Bay of Fundy. Endang Species Res 3:77-94

Murison LD, Gaskin DE (1989) The distribution of right whales and zooplankton in the Bay of Fundy, Canada. Can J Zool 67:1411-1420

Murphy JA, Cohen RE (1979) A guide to the developmental stages of common coastal, Georges Bank and Gulf of Maine copepods. Lab Ref No. 78-53, National Marine Fisheries Service, Northeast Fisheries Center, Woods Hole Laboratory, Woods Hole, MA

Nordøy ES (1995) Do minke whales (Balaenoptera acutorostrata) digest wax esters? Br J Nutr 74:717-722

> Nordøy ES, Sormo W, Blix AS (1993) In vitro digestibility of different prey species in minke whales (Balaenoptera acutorostrata). Br J Nutr 70:485-489

O'Leary WM (1962) The fatty acids of bacteria. Bacteriol Rev $4: 421-447$

Obst B (1986) Wax digestion in Wilson's storm-petrel. Wilson Bull 98:189-195

> Olsen MA, Aagnes TH, Mathiesen SD (1994) Digestion of herring by indigenous bacteria in the minke whale forestomach. Appl Environ Microbiol 60:4445-4455

Olsen MA, Blix AS, Utsi TH, Sormo W, Mathiesen SD (2000) Chitinolytic bacteria in the minke whale forestomach. Can J Microbiol 46:85-94

> Olsen RE, Henderson RJ, Sountama J, Hemre GI, Ringo E, Melle W, Tocher DR (2004) Atlantic salmon, Salmo salar, utilizes wax ester-rich oil from Calanus finmarchicus effectively. Aquaculture 240:433-449

Parrish CC, Ackman RG (1983) The effect of developing solvents on lipid class quantification in chromarod thin layer chromatography/flame ionization detection. J Chromatogr A 262:103-112

Patton JS, Benson AA (1975) A comparative study of wax ester digestion in fish. Comp Biochem Physiol B 52: 111-116

Patton JS, Nevenzel JC, Benson AA (1975) Specificity of digestive lipases in hydrolysis of wax esters and triglycerides studied in anchovy and other selected fish. Lipids 10:575-583

Place AR (1992a) Comparative aspects of lipid digestion and absorption: physiological correlates of wax ester digestion. Am J Physiol 263:464-471

Place AR (1992b) Bile is essential for lipid assimilation in 
Leach's storm petrel, Oceanodroma leucorhoa. Am J Physiol 263:R389-R399

Pond CM (1998) The fats of life. Cambridge University Press, Cambridge

Right Whale Consortium (2008) North Atlantic Right Whale Consortium Sightings Database. New England Aquarium, Boston, MA

Roby DD, Place AR, Ricklefs RE (1986) Assimilation and deposition of wax esters in planktivorous seabirds. J Exp Zool 238:29-41

Roff JC (1978) Fisheries and Marine Service Technical Report 823. Report No. 113, University of Guelph, Guelph

Rolland RM, Hunt KE, Kraus SD, Wasser SK (2005) Assessing reproductive status of right whales (Eubalaena glacialis) using fecal hormone metabolites. Gen Comp Endocrinol 142:308-317

Rolland RM, Hunt KE, Doucette GJ, Rickard LG, Wasser SK (2007) The inner whale: hormones, biotoxins and parasites. In: Kraus S, Rolland RM (eds) The urban whale: North Atlantic right whales at the crossroads. Harvard University Press, Cambridge, MA, p 232-272

Sargent JR (1976) The structure, metabolism and function of lipids in marine organisms. In: Malins DC, Sargent JR (eds) Biochemical and biophysical perspectives in marine biology, Vol 3. Academic Press, London, p $149-212$

Editorial responsibility: Steven Cooke, Ottawa, Ontario, Canada
Sargent JR, Lee RF, Nevenzel JC (1976) Marine waxes. In: Kolattukudy PE (ed) Chemistry and biochemistry of natural waxes. Elsevier, New York, p 49-91

> Sargent JR, McIntosh R, Bauermeiser A, Blaxter JHS (1979) Assimilation of the wax esters of marine zooplankton by herring (Clupea harengus) and rainbow trout (Salmo gairdneri). Mar Biol 51:203-207

Savary P (1971) The action of pure pig pancreatic lipase upon esters of long-chain fatty acids and short-chain primary alcohols. Biochim Biophys Acta 248:149-155

Sergeant DE (1969) Feeding rates of cetacea. Fiskeridir Skr Ser Havunders 15:246-258

Smith DL (1977) A guide to marine coastal plankton and marine invertebrate larvae. Kendall-Hunt, Dubuque, IA

Steel G, Torrie J (1980) Principles and procedures of statistics, a biometric approach. McGraw-Hill Book Co., New York

Warham J (1977) The incidence, functions and ecological significance of petrel stomach oils. Proc NZ Ecol Soc 24: $84-93$

White CR, Seymour RS (2005) Allometric scaling of mammalian metabolism. J Exp Biol 208:1611-1619

Wikelski M, Cooke SJ (2006) Conservation physiology. Trends Ecol Evol 21:38-46

Woodley TH, Gaskin DE (1996) Environmental characteristics of North Atlantic right and fin whale habitat in the lower Bay of Fundy, Canada. Can J Zool 74:75-84

Submitted: June 30, 2008; Accepted: October 10, 2008

Proofs received from author(s): February 2, 2009 